\title{
A ideia de paz, federalismo e prudência em À Paz Perpétua¹ de Kant.
}

\author{
Nicholas Salla*, Prof ${ }^{\mathrm{a}} \mathrm{Dr}^{\mathrm{a}}$ Monique Hulshof
}

\section{Resumo}

O propósito desta pesquisa é analisar o direito público de Kant por meio de suas considerações tardias sobre a paz, federalismo e prudência. Trata-se, no primeiro momento, de articular o seu pensamento para à compreensão da relação entre paz e constituição civil, sob a luz do direito público e sua relação com a política e a moral. Em seguida, busca-se analisar a recusa do autor de uma ideia positiva de uma república mundial em favor do seu sucedâneo negativo, o federalismo de Estados livres. E por fim, sob as considerações sobre a prudência, mobilizo meus esforços para defender que o federalismo é a condição inicial necessária para almejar a paz perpétua, e não uma incoerência do autor.

\section{Palavras-chave:}

Direito kantiano, federalismo, prudência.

\section{Introdução}

O opúsculo À Paz Perpétua foi escrito no estilo de tratados de paz do século XVII, dividido em artigos preliminares, artigos definitivos, dois suplementos e dois apêndices. O autor nos apresenta as condições negativas e positivas para paz, uma garantia da natureza, um suplemento secreto e sua discussão sobre 0 desacordo e acordo da política com a moral Minha proposta é identificar as ideias centrais para a doutrina do direito público kantiano por meio dos conceitos de paz, federalismo e prudência, presentes nos artigos definitivos e no apêndice final da obra. $O$ segundo aspecto que quero pôr em relevo é a dificuldade no texto de interpretar a fundação do direito das gentes por meio do federalismo, recusando a ideia de uma república mundial com poderes coercitivos.

\section{Resultados e Discussão}

Na passagem para a segunda seção, o conceito de paz é posto como um estado oposto ao estado de natureza, visto também como um estado de guerra, pois há sempre o perigo de uma nova eclosão de hostilidades. Para Kant, o estado de paz deve ser instituído, isto é, o fim das hostilidades de todos contra todos só pode ter fim em algum estado legal de direito.

A constituição civil deve ser considerada em três níveis: segundo o direito civil de Estados, das gentes, e cosmopolita. A ideia de paz perpétua só é concebível quando se considera essas três divisões do direito público. Como sugere Kant, se somente uma dessas três divisões estiver no estado de natureza, de sorte estaria ainda um perpétuo estado de guerra.

Apenas em um estado legal legitimado pelo direito público nas três áreas, que assegure a cada indivíduo ou a cada estado o seu direito, poderá haver paz. Os três artigos definitivos contêm os princípios jurídicos para a configuração de cada nível das relações, a saber, "a constituição civil em cada Estado deve ser republicana”; "o direito das gentes deve ser fundado sobre um federalismo de Estados livres"; "o direito cosmopolita deve ser limitado às condições da hospitalidade universal". Meu exame concentrar-se-á no segundo artigo definitivo, sobre o federalismo.

Em linhas gerais, a fundamentação do direito das gentes é dada a partir de quatro elementos, a saber, (1) as relações hostis que os Estados têm praticado entre si não possuem natureza jurídico-legal; (2) mas é antes um estado de guerra (do direito do mais forte), mesmo que não tenha o combate efetivo, que precisa ser superado; (3) é necessária uma aliança entre os povos, análoga a ideia de um contrato social civil; (4) esta aliança não deve ser dotada de poder soberano, pois então ter-se-ia um Estado mundial, mas ser uma associação ou uma federação livre, sempre expansiva e que pode ser renovada.

\section{Conclusões}

A prudência surge como (a) princípio supremo da política ou (b) princípio político subordinado à moral. No primeiro caso, a política é a "arte de utilizar este para o governo dos homens", enquanto a prudência trata de práticas para desorganizar o povo, na medida em que elas são pensadas para a manutenção e execução do poder dominante, independentemente de ser justa ou injusta a constituição atual do Estado. Como princípio subordinado à moral, a prudência serve como pedra angular do progresso do direito; segundo o princípio do político moral, quando detectado um problema na constituição do Estado, a prudência deve ser consultada para decidir quando e como as mudanças devem ser feitas para não arriscar a segurança do Estado e do povo, sem nunca perder de vista a aproximação constante do fim desejado.

Em decorrência disso, não seria mais possível interpretar como desejável fundar o direito das gentes em um Estado mundial, pois seria uma atitude contrária a prudência, mas que deve permanecer como um ideal que deve ser perseguido. Se a princípio a ideia de uma associação entre Estados formando algo semelhante a um Estado universal, como base fundamental para o direito das gentes e o direito cosmopolita, é recusada pelas razões apresentadas, Kant ainda exige que o direito cosmopolita tenha alguma base institucional. Por esse motivo, Kant apresenta um substituto negativo, uma liga federativa, que é uma aliança de povos, e não um Estado de povos.

\section{Agradecimentos}

Gostaria de agradecer a minha orientadora, Monique Hulshof, por seu suporte e incentivo a esta pesquisa.

1 KANT, Immanuel. Á Paz perpétua, um projeto filosófico, tradução de Marco A. Zingano, São Paulo: L\&PM Editores, 1989. 